\title{
BLOOD PARAMETERS AND APPARENT DIGESTIBILITY OF CONCENTRATE WITH RICE OIL FOR HORSES
}

\author{
Parâmetros plasmáticos e digestibilidade aparente em equinos recebendo \\ concentrado com óleo de arroz
}

\author{
Helio Alberto Cumani Garcia ${ }^{1}$, Carlos Eduardo Furtado², Roberta Ariboni Brandi ${ }^{3}$, \\ Mara Regina Schimmack Pedro Soncin ${ }^{1}$, Júlio Cesar de Carvalho Balieiro ${ }^{3}$, Aline Duarte de Souza ${ }^{3}$
}

\begin{abstract}
Apparent digestibility coefficients and serum parameters were measured to evaluate the effect of supplementing feed concentrates with rice bran oil in horses. Twelve horses (6 males and 6 females) with a mean age of $18 \pm 4$ months old and mean live weight of $306 \pm 22.6 \mathrm{~kg}$ were used. Treatments consisted of increasing rice bran oil concentrate levels of $0,3.5,7.0,10.5,14.0$ and $17.5 \%$, considering a daily intake of $2.25 \%$ live weight on a dry matter basis. A dietary effect of supplementation on the apparent digestibility of gross energy $(y=64.55-0.58 x)$ was observed $(P<0.05)$. No effect on the other nutrients was observed $(P>0.05)$. Supplementation did not affect serum glucose levels $(\mathrm{P}>0.05)$, but cholesterol was affected $(\mathrm{P}<0.01)$ based on the interaction of the treatment $x$ gender parameter in females $(y=73.92+2.08 x)$. However, no effect was observed in males $(P>0.05)$. A dietary effect on the triglyceride $\left(\mathrm{y}=15.73-0.96 \mathrm{x}+0.0524 \mathrm{x}^{2}\right)$ and HDL (high-density lipoprotein) $(\mathrm{y}=45.24+1.0499 \mathrm{x})$ parameters was observed $(\mathrm{P}<0.01)$. While the use of rice bran oil does affect blood parameters associated with lipid metabolism, rice bran oil levels up to $17.5 \%$ concentrate do not negatively affect the apparent digestibility of dietary nutrients.
\end{abstract}

Index terms: Nutrition, oil, serum, foals.

\section{RESUMO}

O experimento foi conduzido para avaliar o efeito da adição do óleo de arroz em concentrados para equinos, por meio de ensaio de digestibilidade aparente e de parâmetros plasmáticos (glicose, colesterol, triglicerídeos e lipopoliproteinas de alta densidade - HDL). Foram utilizados 12 equinos, seis machos e seis fêmeas, com idade média $18 \pm 4$ meses e peso vivo de $306 \pm 22,6 \mathrm{~kg}$. Os tratamentos utilizados constituíram de níveis crescentes de óleo de arroz no concentrado sendo 0,$0 ; 3,5 ; 7,0 ; 10,5 ; 14,0$ e $17,5 \%$, adotadando a ingestão diária de $2,25 \%$ do $\mathrm{PV}$ de MS. Foi observado efeito $(\mathrm{P}<0,05)$ entre as dietas somente sobre a digestibilidade aparente da energia bruta $(y=64,55-0,58 x)$. Não houve efeito $(P>0,05)$ das dietas sobre o nível sérico de glicose, entretanto para o parâmetro colesterol foi verificado efeito $(\mathrm{P}<0,01)$ para a interação tratamento $\mathrm{x}$ sexo, sendo significativo para as fêmeas representado por $(\mathrm{y}=73,92+2,08 \mathrm{x})$. Já, para os machos, não houve efeito $(\mathrm{P}>0,05)$. Considerando o parâmetro triglicerídeo houve efeito $(\mathrm{P}<0,01)$ das dietas $\left(\mathrm{y}=15,73-0,96 \mathrm{x}+0,0524 \mathrm{x}^{2}\right)$. Observou-se efeito $(\mathrm{P}<0,01)$ sobre o parâmetro sérico de HDL $(\mathrm{y}=45,24+1,0499 \mathrm{x})$. O óleo de arroz pode ser utilizado em concentrado para equinos em crescimento.

Termos para indexação: Nutrição, óleo, plasma, potros.

(Received in april 4, 2013 and approved in july 25, 2013)

\section{INTRODUCTION}

Horses are classified as non-ruminant herbivores with functional cecum and colons. The anatomical and physiological features of horses enable them to effectively absorb dietary carbohydrates and lipids before the action of microbiota in the large intestine (FRAPE, 2008).

High dietary starch contents and limited digestive capacity can hinder the digestion of soluble carbohydrates in the small intestine, thereby increasing the supply of readily fermentable carbohydrates to the cecum and colon, which contributes to the onset of metabolic and digestive problems (such as colic, endotoxemia and laminitis). The use of lipids in horse diet is a feasible alternative to increase the energy density of food without correspondingly increasing the level of dry matter intake. Therefore, the addition of lipids enables a decrease in the amount of concentrate ingested (HINEY; POTTER, 1996).

The use of oils and fats in horse feed and their effects on the digestibility of fiber and its components are controversial. Some authors (BUSH et al., 2001; KRONFELD et al., 2004) have found no correlation between dietary supplementation with lipids and fiber digestibility, but other authors (JANSEN et al., 2000) found that dietary

${ }^{1}$ Universidade Estadual de Maringá/UEM - Maringá - PR - Brasil

2Universidade Estadual de Maringá/UEM - Maringá - PR - Brasil - cefurtado@uem.br

${ }^{3}$ Universidade de São Paulo/USP - Faculdade de Zootecnia e Engenharia de Alimentos/FZEA - Pirassununga - SP - Brasil 
supplementation with high amounts of oil reduces the digestibility of fiber components.

Kronfeld et al. (2004) studied fat digestibility in Equus caballus and found that ether extract digestibility varies among forages, grains and dietary supplementation with oil based on the levels of triglycerides.

In a study of the effect of corn oil supplementation in horse diets on nutrient digestibility, Resende Junior et al. (2004) found no significant effect of oil supplementation on dry matter, crude protein, fiber or neutral and acid detergent fiber digestibility. However, the authors found significant differences in gross energy and ether extract digestibility.

Studies of rice bran oil in horse feed are scarce. Frank et al. (2005) found that serum levels of unsaturated fatty acids and triglycerides decrease upon diet supplementation with rice bran oil in mares. Godoi et al. (2009) assessed oil supplementation in horse diets and found that dietary supplementation with $19.5 \%$ soybean oil increased serum triglyceride levels compared to a diet without lipid supplementation.

The aim of the present study was to evaluate the effect of supplementation with increasing levels of rice bran oil on the apparent digestibility coefficient of nutrients and on serum glucose, cholesterol, triglyceride and highdensity lipoprotein (HDL) levels in horses.

\section{MATERIALS AND METHODS}

The experiment was conducted at Iguatemi Experimental Farm, Maringá State University
(Universidade Estadual de Maringá - UEM), from January to March 2010.

Twelve crossbred (English Thoroughbreds crossed with Mangalarga) foals ( 6 males and 6 females) with a mean age of $18 \pm 4$ months old and live weight of $306 \pm 22.6 \mathrm{~kg}$ were used. The horses were housed in individual stalls. Two animals were used per treatment - one male and one female for each treatment.

During a period of 90 days, the animals were fed the experimental diets formulated as recommended by the NATIONAL RESEARCH COUNCIL - NRC (2007) for growing foals (18 months), considering an intake of $2.25 \%$ live weight on a dry matter basis. Treatment consisted of concentrate supplementation with $0,3.5,7.0,10.5,14.0$ and $17.5 \%$ rice bran oil (Tables1 and 2), with a defined 50:50 roughage (Tifton 85)-to-concentrate ratio. The diets were partitioned into three daily meals, supplied at 7 hours 30 minutes, 13 hours and 17 hours.

The animals were exercised during the morning, twice a week throughout the experiment. The exercise protocol was divided into two stages. In the first stage (a 7 -week period), the animals walked for 3 minutes, trotted for 3 minutes and walked again for 3 minutes, for a total of 18 minutes of exercise with equal training on both the left and right sides. In the second stage (a 4-week period), this protocol was maintained, but the trotting time was increased by 4 minutes, for a total of 22 minutes of exercise.

For the digestibility assay, feces were collected in totality, for four days in the last experimental week.

Table 1 - Percent composition of experimental concentrates.

\begin{tabular}{|c|c|c|c|c|c|c|}
\hline \multirow{2}{*}{ Ingredient } & \multicolumn{6}{|c|}{ Percent inclusion of rice oil } \\
\hline & 0 & 3.5 & 7 & 10.5 & 14 & 17.5 \\
\hline Corn & 65.10 & 61.30 & 57.30 & 53.30 & 50.00 & 45.00 \\
\hline Wheat Bran & 10.00 & 10.00 & 10.00 & 10.00 & 10.00 & 10.00 \\
\hline Soybean Meal & 19.00 & 20.00 & 20.50 & 21.00 & 22.00 & 23.00 \\
\hline Rice Oil & 0.00 & 3.50 & 7.00 & 10.50 & 14.00 & 17.50 \\
\hline Dicalcium Phosphate & 1.30 & 1.00 & 1.00 & 1.00 & 1.00 & 1.00 \\
\hline Limestone & 2.40 & 2.50 & 2.50 & 2.50 & 1.80 & 2.30 \\
\hline Salt & 2.00 & 1.50 & 1.50 & 1.50 & 1.00 & 1.00 \\
\hline Mineral Supplement ${ }^{1}$ & 0.10 & 0.10 & 0.10 & 0.10 & 0.10 & 0.10 \\
\hline Vitamin Supplement $^{2}$ & 0.10 & 0.10 & 0.10 & 0.10 & 0.10 & 0.10 \\
\hline Total & 100 & 100 & 100 & 100 & 100 & 100 \\
\hline
\end{tabular}

${ }^{1}$ Mineral supplement: P-72g. Ca-191 g. Na-68.25 g. Cl-105 g. Mg-27.5 g. S-14.963 g, Zn-1,500 mg, Cu-250 mg, Mn-1,000 mg, Fe$1,000 \mathrm{mg}$, Co-12.24 mg, I-20.00 mg, Se-2.25 mg, Fl (Max)-0.72 mg. ${ }^{2}$ Vitamin supplement: vit. A-1,600,000UI, vit D3-200,000UI, vit E-3,000UI, vit K3-636 mg, vit B1-1,200 mg, vit B2-1,600 mg, vit B12-3,300 mg, B5-3,3300 mg, B7-20 mg, PP-6,000 mg, B9$200 \mathrm{mg}$, choline- $40 \mathrm{mg}$, L-Lysine- $25 \mathrm{mg}$, antioxidant-200 mg.

Ciênc. agrotec., Lavras, v. 37, n. 5, p. 435-442, set./out., 2013 
Table 2 - Chemical composition of the Tifton Hay 85 and of the experimental concentrates.

\begin{tabular}{|c|c|c|c|c|c|c|c|}
\hline \multirow{2}{*}{ Nutrients } & \multicolumn{7}{|c|}{ Treatment (Percent inclusion of rice oil) } \\
\hline & Hay & 0 & 3.5 & 7 & 10.5 & 14 & 17.5 \\
\hline $\mathrm{DM}^{1}(\%)$ & 90.60 & 90.23 & 89.94 & 90.21 & 90.09 & 89.45 & 89.71 \\
\hline $\mathrm{CP}^{2}(\%)$ & 7.70 & 17.37 & 16.50 & 18.06 & 19.08 & 19.89 & 17.96 \\
\hline $\operatorname{NDF}^{3}(\%)$ & 85.19 & 25.65 & 28.11 & 24.17 & 22.90 & 25.26 & 24.53 \\
\hline $\operatorname{ADF}^{4}(\%)$ & 45.82 & 6.59 & 5.00 & 4.96 & 5.24 & 5.38 & 4.99 \\
\hline $\mathrm{EE}^{5}(\%)$ & 1.20 & 2.68 & 6.70 & 10.56 & 14.43 & 19.36 & 25.41 \\
\hline \multirow[t]{2}{*}{$\mathrm{GE}^{6}(\mathrm{Mcal} / \mathrm{kg})$} & 3.91 & 3.68 & 3.84 & 4.13 & 4.27 & 4.48 & 4.62 \\
\hline & \multicolumn{7}{|c|}{ Chemical composition of the diets evaluated } \\
\hline $\mathrm{DM}^{1}(\%)$ & & 90.41 & 90.27 & 90.41 & 90.34 & 90.07 & 90.19 \\
\hline $\mathrm{CP}^{2}(\%)$ & & 12.52 & 11.99 & 12.68 & 13.05 & 13.26 & 12.31 \\
\hline $\operatorname{NDF}^{3}(\%)$ & & 55.48 & 57.33 & 55.80 & 55.87 & 57.79 & 57.88 \\
\hline $\operatorname{ADF}^{4}(\%)$ & & 26.24 & 25.89 & 26.14 & 26.72 & 27.33 & 27.44 \\
\hline $\mathrm{EE}^{5}(\%)$ & & 1.97 & 3.91 & 5.74 & 7.45 & 9.53 & 12.13 \\
\hline $\mathrm{GE}^{6}(\mathrm{Mcal} / \mathrm{kg})$ & & 3.85 & 3.93 & 4.07 & 4.13 & 4.22 & 4.28 \\
\hline
\end{tabular}

${ }^{1} \mathrm{DM}$ - Dry Matter. ${ }^{2} \mathrm{CP}$ - Crude Protein, ${ }^{3} \mathrm{NDF}-$ Neutral Detergent Fiber, ${ }^{4} \mathrm{ADF}-$ Acid Detergent Fiber, ${ }^{5} \mathrm{EE}-\mathrm{Ether}$ extract,

${ }^{6} \mathrm{~EB}-$ Gross Energy.

The feces were collected immediately following animal defecation and stored in properly identified plastic containers to be weighed 24 hours after collection. The samples were homogenized, and an aliquot of $10 \%$ total feces was removed, weighed and pre-dried in a convection oven at $55^{\circ} \mathrm{C}$ for 72 hours at the end of each collection day. Samples were sent for analysis after predrying.

The bromatological analyses of food and feces were performed at the Laboratory of Animal Nutrition (Laboratório de Nutrição Animal - LANA) of the Animal Science Department (Departamento de Zootecnia - DZO) of UEM according to the method suggested by Silva (2002).

The apparent digestibility coefficients of Dry Matter (DM), Crude Protein (CP), Neutral Detergent Fiber (NDF), Acid Detergent Fiber (ADF), Ether Extract (EE) and Gross Energy (GE) were assessed.

Blood samples were collected (following animal adaptation to exercise) for analysis of blood parameters on the $66^{\text {th }}, 78^{\text {th }}$ and $90^{\text {th }}$ day after beginning the experimental protocol and before the first dairy feed of the foals. Blood was collected by venipuncture of the left jugular vein into Vacutainer tubes to measure glucose, cholesterol, triglyceride and HDL levels. A fraction of the total blood collected was kept cooled and sent for glucose and triglyceride analysis, while the remainder was immediately centrifuged for 15 minutes at 3,000 rpm, and the plasma was collected and stored at $-20{ }^{\circ} \mathrm{C}$ for subsequent cholesterol and HDL analysis.

Serum parameters, including glucose, cholesterol, triglycerides and HDL, were assessed using biochemical kits and spectrophotometry.

The data from the completely randomized design used for the apparent digestibility trial were statistically analyzed using Bayesian inference at a 5\% significance level, analyzed by Saeg program.

All the results were analyzed using the STATISTICALANALYSIS SYSTEM SOFTWARE - SAS (2001). The experimental design used for the blood parameters was a split-plot with repeated measurements over the time. The serum parameter data were assessed using a mixed model considering the animal as the random effect and the following parameters as fixed effects: time, treatment, gender and the interaction of gender $\mathrm{x}$ treatment, in addition to the residuals. Because the treatment is a quantitative variable, regression analyses were performed upon the identification of significant results, at $5 \%$ significance level.

\section{RESULTS AND DISCUSSION}

Supplementation with rice bran oil did not affect DM, CP, EE, NDF or ADF digestibility ( $\mathrm{P}>0.05)$ (Table 3). Supplementation did affect GE digestibility $(\mathrm{P}<0.05)$. 
Table 3 - Apparent nutrient digestibility coefficients in diets for equines with different levels of rice oil in the treatments ( $\%$ oil level in the concentrate).

\begin{tabular}{ccc}
\hline Variables & Equations & CV (\%) \\
\cline { 2 - 3 } aDCDM $^{1}$ & 61.77 & 7.92 \\
aDCCP $^{2}$ & 71.62 & 4.75 \\
aDCEE $^{3}$ & 89.09 & 3.53 \\
aDCNDF $^{4}$ & 51.62 & 14.06 \\
aDCADF $^{5}$ & 41.86 & 20.44 \\
\hline
\end{tabular}

1 - Apparent Digestibility Coefficient of Dry Matter . 2 Apparent Digestibility Coefficient of Crude Protein. 3 Apparent Digestibility Coefficient of Ether Extract. 4 Apparent Digestibility Coefficient of Neutral Detergent Fiber. 5 - Apparent Digestibility Coefficient of Acid Detergent Fiber.

Using 3.2\% rice bran oil in horse diets, Gonzaga et al. (2012) reported digestibility coefficient values of 64.64, 71.95, 83.37, 62.15 and 55.05 for DM, CP, EE, NDF and ADF. respectively; these values are similar to those measured in the present study.

In contrast, Brandi et al. (2007) assessed supplementation with increasing oil levels (up to $24 \%$ in concentrate) and detected a difference in the DM apparent digestibility coefficient $(\mathrm{P}<0.05)$ and the digestibility observed using the equation $y=76.927+0.006858 \mathrm{x}+$ $0.00665861 \mathrm{x}^{2}$, with the highest digestibility found with $24 \%$ oil levels. These authors, also reported differences in the digestibility coefficients of NDF and ADF $(\mathrm{P}<0.05)$. represented by the equations $y=69.9201+0.0610912 x+$
$0.005868 \mathrm{x}^{2}$ and $\mathrm{y}=6.3+6.21074 \mathrm{x}-0.138393 \mathrm{x}^{2}$, respectively, and differences in the EE digestibility coefficient $(\mathrm{y}=78.365$ $\left.-0.1018 \mathrm{x}+0.03594 \mathrm{x}^{2}\right)(\mathrm{P}<0.05)$ between diets supplemented with increasing levels of soybean oil. These differences can be attributed to the class of animal used, type and intensity of exercise and amount and source of oil.

No effect of oil level on EE digestibility coefficients was observed in this study, unlike the findings by Brandi et al. (2007). Diets with $17.5 \%$ oil may have high dietary utilization without negatively affecting the digestibility of the fiber fraction, as reported by Jansen et al. (2000). The maintenance of a roughage-to-concentrate ratio of 50:50 may have greatly contributed to the maintenance of NDF $(51.62 \%)$ and $\mathrm{ADF}(41.86 \%)$ digestibility coefficients. as previously reported by the NRC (2007).

Figure 1 shows the apparent digestibility values of digestible energy in horse diets supplemented with increasing levels of rice bran oil in the present experiment.

A negative effect of increasing oil inclusion levels was observed on the apparent digestibility of GE; the control diet displayed the highest apparent digestibility coefficient (65.71\%), while the diet with the highest level of rice bran oil (17.5\%) displayed the lowest apparent digestibility coefficient (53.89\%). A noticeable variation between the estimated and experimental values was observed (Figure 1), suggesting that variations between animals can affect energy digestibility based on repeated evaluations of the same animals over a short time period. Additionally, the animal class (foals) and training protocol may have affected the dietary utilization of this source.

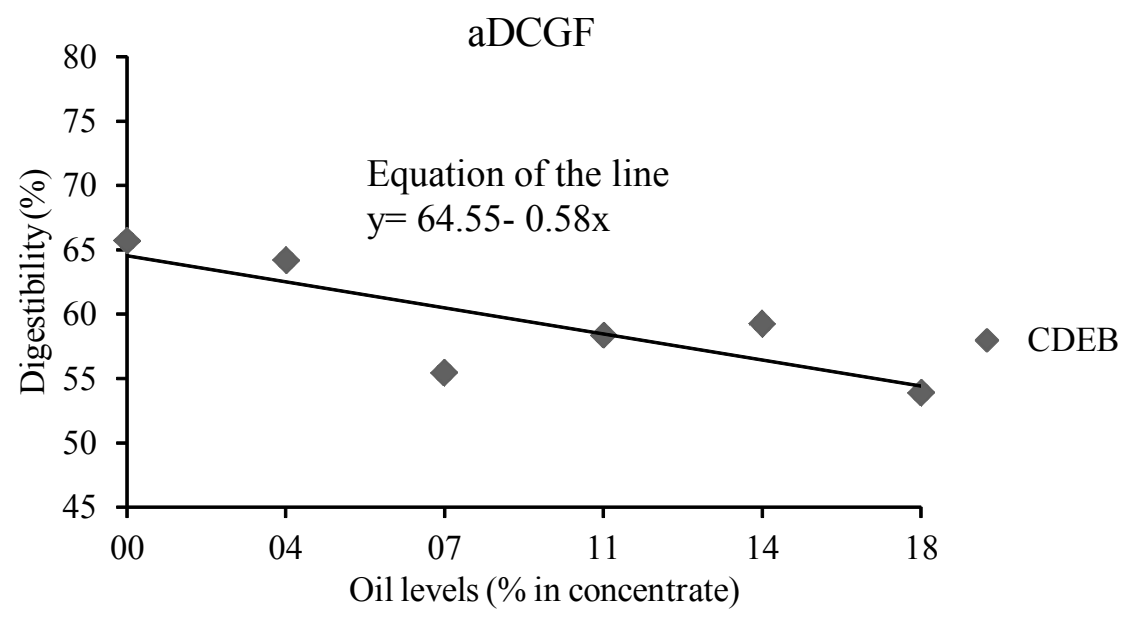

Figure 1 -Apparent Digestibility Coefficient of Gross Energy (GE) of diets for equines with different levels of rice oil. 
Other studies that have assessed the effects of oil levels in horse diets on GE digestibility coefficients have reported results that contrast with those in the present study. Brandi et al. (2007) found a GE digestibility coefficient value of $y=7.60363+0.400505 x-0.177206 x 2$, with the $12 \%$ oil level as the inflection point, when using adult horses and assessing moderate energy-demand horse diets supplemented with different levels of soybean oil. Moreover, Godoi et al. (2009) found no significant difference between treatments when assessing soybean oil levels $(0,8.5$ and $19.5 \%)$ in animals submitted daily to moderate physical activity, reporting GE digestibility coefficient values of 63.0, 66.2 and 67.1\%. respectively.

Dietary oil supplementation and digestibility of the lipid fraction affected the triglyceride and HDL blood levels (Table 4).

The interaction of treatment $\mathrm{x}$ gender was found to affect cholesterol $(\mathrm{P}<0.01)$ (Figure 2).
Manzano et al. (1995) found significant increases in serum cholesterol levels upon diet supplementation with $0.5 \%$ soybean oil and $5.5 \%$ animal fat, but no gender effects were reported. Similar to the present study, Ropp et al. (2003) reported increased serum cholesterol levels in horses fed lipid-rich foods compared with those fed conventional foods.

According to Bertan et al. (2006), the gender effect observed in the present study may result from the process of corpus luteum (CL) formation, wherein cholesterol is the main substrate for progesterone production. Cholesterol is primarily synthesized in the liver, then transported in the form of lipoproteins to all steroidogenic tissues, including the adrenal cortex, ovarian follicles and CL. The increase in serum cholesterol levels found in the present study may also be linked to the onset of the estrous cycle in the fillies during the experiment because these animals were, on average. 18 months old.

Table 4 - Regression equations of blood parameters with treatment effect and of interaction treatment $\mathrm{x}$ sex evaluated in equines undergoing diet containing rice oil.

\begin{tabular}{lccc}
\hline \multirow{2}{*}{ Variables } & Treatment & \multicolumn{2}{c}{ Treatment $\mathrm{x}$ Sex } \\
\cline { 3 - 4 } & $86.16^{*}$ & --- & Memale \\
\hline Glucose & -- & $80.68^{*}$ & --- \\
Cholesterol & $\mathrm{y}=15.73-0.96 \mathrm{x}+0.0524 \mathrm{x}^{2} * *$ & -- & $\mathrm{y}$ \\
Triglycerides & $\mathrm{y}=45.24+1.0449 \mathrm{x} * *$ & -- & -- \\
HDL & & -- \\
\hline
\end{tabular}

Values followed by $*$ not have any significant effect $(\mathrm{P}<0.05)$ at $5 \%$.

Values followed by $* *$ show significant effect $(\mathrm{P}<0.01)$ at $1 \%$.

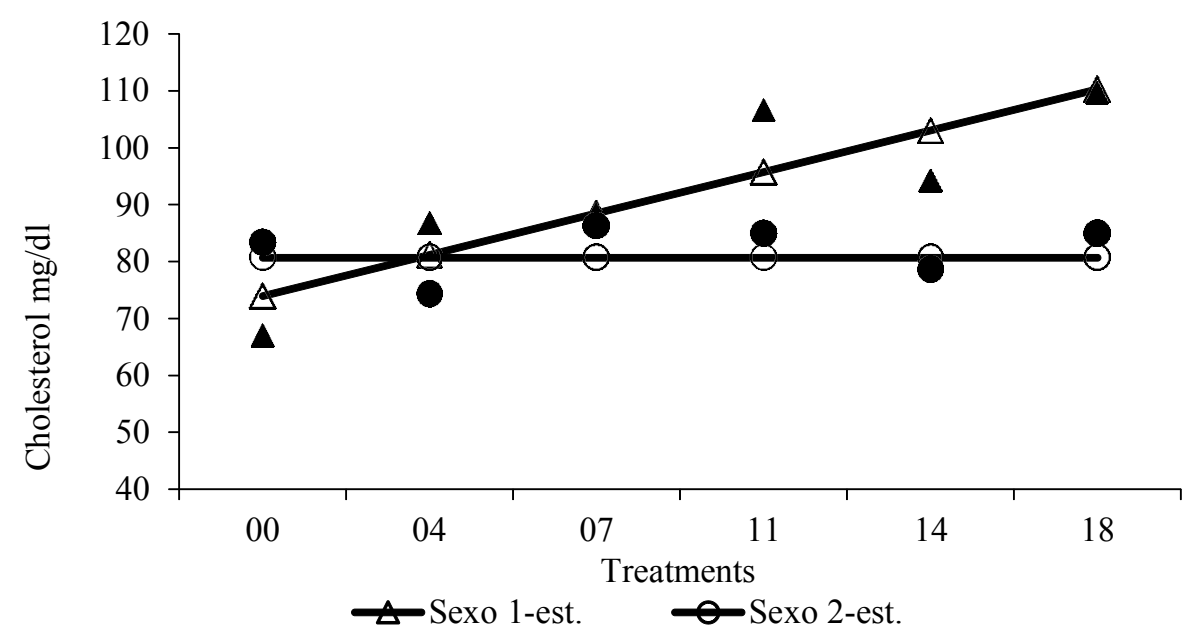

Figure 2 - Effect of variable interaction diet $\mathrm{x}$ sex on the values of plasma cholesterol (mg / dl). 
A treatment effect was observed for the triglyceride and HDL variables $(\mathrm{P}<0.05)$ (Figure 3 ).

A dietary effect was observed on the triglyceride parameter $(\mathrm{P}<0.01)$. Godoi et al. (2009) assessed soybean oil levels of $0,8.5$ and $19.5 \%$ in horse diets and found a significantly higher triglyceride value in the diet with $19.5 \%$ oil $(\mathrm{P}<0.05)$, with increasing values of 39.5. 46.2 and 57.0 $\mathrm{mg} / \mathrm{dl}$ in the respective diets. These values are higher than those found in the present study; the differences may be attributed to the animal class and source of oil used in the studies.

The values measured in the present study and those reported in the literature suggest that the performance of triglycerides is related to the lipid levels in the diets and that a still undefined maximum value of supplementation with lipids exists and can cause a significant increase in serum triglyceride levels. According to Dutra-de Oliveira and Marchini (1998), non-oxidized fatty acids form triglycerides, and excess triglycerides are stored or used by other tissues as an energy source when their synthesis exceeds the requirements for lipoprotein formation. These observations suggest a possible mechanism for the increase in triglyceride concentrations resulting from a given intake level.

A significant treatment effect was observed on HDL $(\mathrm{P}<0.01)$ (Figure 4). which may be explained by Marchello et al. (2000). These authors reported that increasing dietary fat increases bile production, which consequently increases endogenous cholesterol absorption, thereby increasing the HDL levels. The same effect was reported by Geelen (1999), who found a correlation between increased soybean oil levels and increased lipoprotein lipase (LPL) activity. The author explained that the increase in serum HDL in horses fed hyperlipidic diets resulted from increased LPL activity; this increased activity caused increased triglyceride removal from VLDL (very low-density lipoprotein), and the surface material (including cholesterol) of VLDL transferred to HDL, resulting in an increased fraction of cholesterol in HDL.

Conversely, Ribeiro et al. (2009) assessed different lipid sources in horse diets and found no significant difference between a control diet and diets supplemented with animal fat and vegetable oil, with values of 76.0. 73.2 and $74.75 \mathrm{mg} / \mathrm{dl}$, respectively. Similarly, Gonzaga et al. (2012) compared soybean and rice bran oils in stallion diets and found no significant difference in the HDL parameter with gender between treatments.

Supplementation with rice bran oil did not affect glucose levels $(\mathrm{P}>0.05)$, which is consistent with the literature on the subject. Oliveira et al. (2010) assessed the effect of rice bran and soybean oils in horse diets and failed to measure a significant difference in glucose concentrations when the animals were assessed at rest or following exercise. Marqueze Kessler and Bernadi (2001) found no significant differences in glucose levels using horse diets with 0 and $7.8 \%$ soybean oil levels; the glucose concentrations were 106.0 and $107.8 \mathrm{mg} / \mathrm{dl}$ in soybean oil-supplemented and control diets, respectively. Dutra-de-Oliveira and Marchini (1998) corroborated the

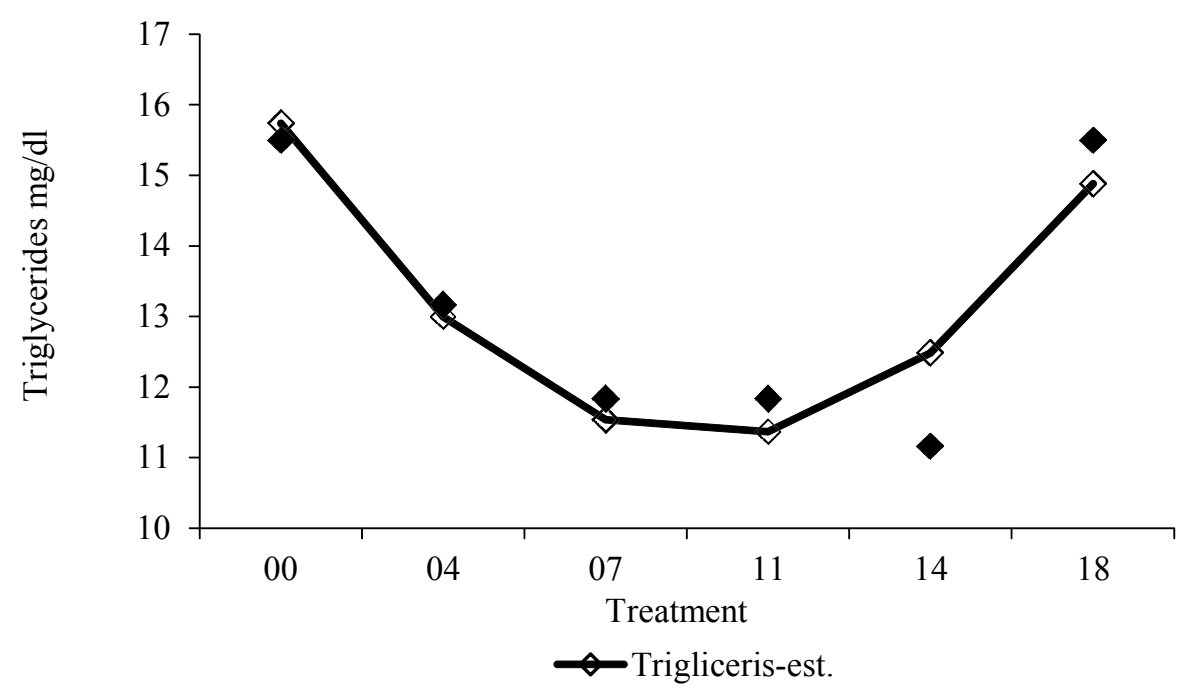

Figure 3-Effect of diets (inclusion levels of rice oil) on the values of the concentration of triglycerides. 


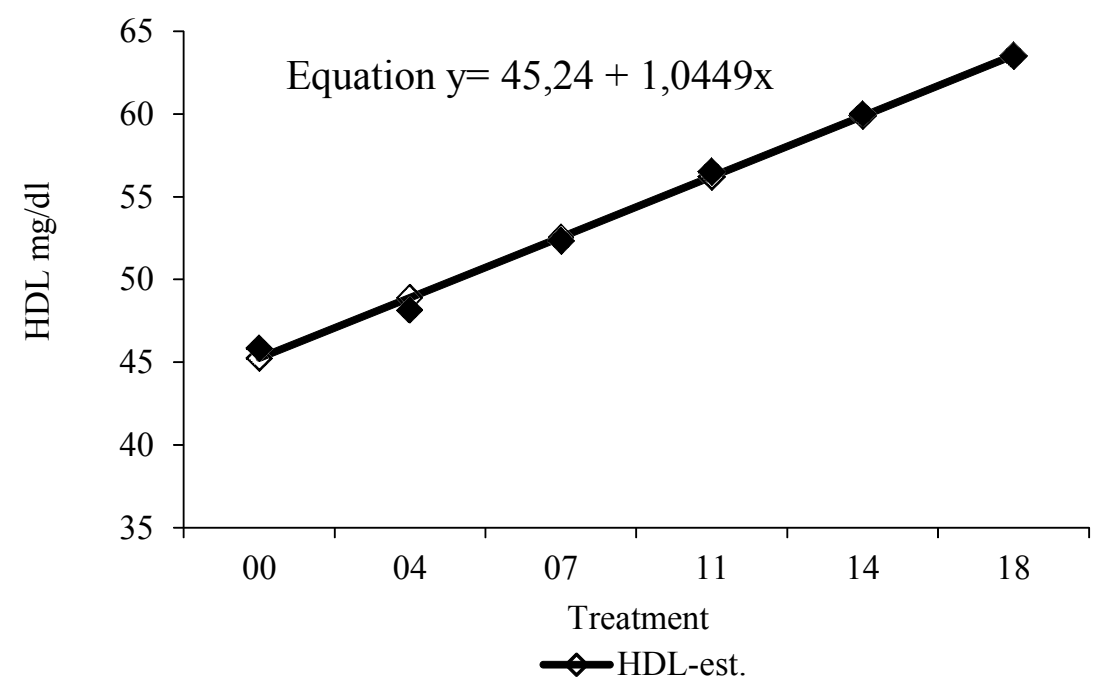

Figure 4 - Effect of diets (inclusion levels of rice oil) on the values of the concentration of triglycerides.

data shown in the present study, reporting that lipid intake does not significantly affect glucose or insulin blood levels, and these parameters directly correlate with carbohydrate intake. Conversely, Harkins et al. (1992) found a significant increase in serum glucose levels in horses fed corn oil-supplemented diets equivalent to $10 \%$ digestible energy. According to the authors, the results may be affected by the amount and form of supply of soybean oil and especially the period of diet intake. indicating that the values may be related to animal adaptation to the diet.

\section{CONCLUSION}

The use of rice bran oil at levels up to $17.5 \%$ concentrate affect lipid metabolism-related blood parameters but does not negatively affect the apparent digestibility of dietary nutrients.

\section{REFERENCES}

BERTAN, C. M. et al. Mecanismos endócrinos e moleculares envolvidos na formação do corpo lúteo e na luteólise. Brazilian Journal of Veterinay Research and Animal Science. São Paulo, v. 43, n. 6, p. 824-840, 2006.

BRANDI, R. A.; FURTADO, C. E. Digestibilidade dos nutrientes de dietas compostas por níveis crescentes de óleo de soja fornecidos a cavalos de enduro. Revista Brasileira de Medicina Equina. São Paulo, v. 3, n. 13, p. 30-34, 2007.
BUSH, J. A. et al. Dietary fat supplementation effects of in vitro nutrient disappearance and in vivo nutrient intake and total tract digestibility by horses. Journal of Animal Science. Columbia, v. 79, n. 1, p 232-239, 2001.

\section{DUTRA-OLIVEIRA, J. E.; MARCHINI, J. S. Ciências}

Nutricionais. 1.ed. São Paulo: Sarvier. 1998. 400.

FRAPE, D. Nutrição \& alimentação de equinos. 3.ed. São Paulo: Roca, 2008. 602 p.

FRANK, N. et al. Effects of rice bran oil on plasma lipid concentrations, lipoprotein composition and glucose dynamics in mares. Journal of Animal Science. Columbia, v. 83, n. 11, p. 2509-2518, 2005.

GEELEN, S.N.J.; OLDRUITENBORGH-OOSTERBAAN, M.M.S.; BEYNEN, A.C. Dietary fat supplementation and equineplasma lipid metabolism. Equine Veterinary Journal. Utrech, v. 30, p. 475-478, 1999.

GODOI, F. N. et al. Consumo cinética digestiva e digestibilidade de nutrientes em eqüinos atletas alimentados com dietas contendo óleo de soja. Revista Brasileira de Zootecnia. Viçosa, v.38, n.10, p.1928-1937, 2009.

GONZAGA, I. V. F. et al. Qualidade espermática e perfil plasmático de lipídeos em garanhões suplementados com óleo de arroz semi-refinado com alto teor de gama-orizanol. Brazilian Journal of Veterinary Research and Animal Science. São Paulo, v. 49, p. 215-220, 2012. 
HARKINS, J. D.; MORRIS, G;; TULLEY, R. T. Effect of added dietary fat on racing performance in Thoroughbred horses. Journal of Equine Veterinary Science. Illinois, v.12, n.2, p.123-129, 1992.

HINEY, K. M.; POTTER, G. D. A review of recent research on nutrition and metabolism in the athletic horse.

Nutrition Research Reviews. New York, v. 9, p. 149-173, 1996.

JANSEN, W. L.; VAN DER KUILEN, J.; GEELEN, S. N. J. The effect of replacing nonstructural carbohydrates with soybean oil on the digestibility of fibre in trotting horses. Equine Veterinay Journal. Cambridgeshire, v. 31, p. 27-30, 2000.

KRONFELD, D. S.; HOLLAND, J. L.; RICH, G. A. Fat digestibility in Equus caballus follows increasing firstorder kinetics. Journal of Animal Science. Columbia, v.82, n., 6, p.1773-1780, 2004.

\section{MANZANO, A.; WANDERLEY, R. C.; ESTEVES, S.N.}

Óleo de soja e gordura animal na alimentação de equinos. Revista Brasileira de Zootecnia, v. 24, n. 5, p. 788-799, 1995.

MARCHELLO, E. V. et al. Changes in lipoprotein composition in horses fed a fat-supplemented diet. Journal of Equine Veterinary Science. Illinois, v. 20, n. 7, p. 453-458, 2000.

MARQUEZE, A.; KESSLER, A. M.; BERNADI, M. L. Aumento do nível de óleo em dietas isonergéticas para cavalos submetidos a exercício. Ciência Rural. Santa Maria, v. 31, p. 491-496, 2001.
NATIONAL RESEARCHCOUNCIL - NRC. Nutrient Requeriments of Horses. Washigton, 5 revised ed. 2007. $341 \mathrm{p}$.

OLIVEIRA, R. N.; XAVIER, A. P. M. J.; ALVES, G. E. S.; Avaliação hematológica e bioquímica de equinos suplementados com óleo de arroz semi-refinado, rico em gamaorizano. Arquivo Brasileiro de Medicina

Veterinária e Zootecnia, v.62, p.1043-1047, 2010.

REZENDE JÚNIOR, T. et al. Efeito do nível de óleo de milho adicionado à dieta de equinos sobre a digestibilidade dos nutrientes. Arquivo Brasileiro de Medicina Veterinária e Zootecnia, v.56, n.1, p.78-85, 2004.

RIBEIRO, R. M. et al. Efeito da inclusão de diferentes fontes lipídicas e óleo mineral na dieta sobre a digestibilidade dos nutrientes e os níveis plasmáticos de gordura em eqüinos. Revista Brasileira de Zootecnia. Viçosa, v. 38, n. 10, p.1989-1994, 2009.

ROPP, J. K.; RAUB, R. H.; MINTON, E. The effect of dietary source on serum concentration of insulin-like growth factor-I. Growth hormone, insulin, glucose and fat metabolites in weanling horses. Journal of Animal Science. Columbia, v. 81, n. 6, p. 1581-1589, 2003.

SILVA, D.J.; QUEIROZ, A. C. Análise de alimentos: métodos químicos e biológicos. 3 ed. Viçosa: Editora UFV, 2002, $235 \mathrm{p}$.

STATISTICALANALYSIS SYSTEM - SAS. SAS user's guide: estatistics. Eletronic version 8.1. Cary: 2001 (CDROM). 